This is an electronic reprint of the original article. This reprint may differ from the original in pagination and typographic detail.

Author(s): Kamran, Sohail; Uusitalo, Outi

Title: Vulnerability of the unbanked : evidence from a developing country

Year: $\quad 2016$

Version:

Please cite the original version:

Kamran, S., \& Uusitalo, O. (2016). Vulnerability of the unbanked : evidence from a developing country. International Journal of Consumer Studies, 40(4), 400-409. https://doi.org/10.1111/ijcs.12277

All material supplied via JYX is protected by copyright and other intellectual property rights, and duplication or sale of all or part of any of the repository collections is not permitted, except that material may be duplicated by you for your research use or educational purposes in electronic or print form. You must obtain permission for any other use. Electronic or print copies may not be offered, whether for sale or otherwise to anyone who is not an authorised user. 


\title{
Vulnerability of the unbanked: Evidence from a developing country
}

\begin{abstract}
Financial exclusion is an apparent phenomenon globally, the majority of people without bank accounts living in the developing countries. Those who lack access to financial services could experience vulnerability. Therefore, the purpose of this study was to unfold the vulnerability of the low-income unbanked consumers in a Pakistani context. Qualitative data were gathered from low-income unbanked consumers through in-depth interviews. The findings suggest that unbanked consumers are vulnerable in many ways. The participants faced several negative consequences due to their financial exclusion, which resulted into their personal, economic and social detriment. Based on our study findings, we provide managerial and public policy implications for the well-being of the low-income unbanked consumers. Lastly, study limitations and future study guidelines are discussed.
\end{abstract}

Keywords: Consumer vulnerability; Unbanked consumers, Financial exclusion; Lowincome consumers, Developing countries; Consumer well-being 


\section{Introduction}

Globally, over 2.5 billion adults have no bank account and the majority of those live in developing countries (Demirgüç-Kunt and Klapper, 2012). For instance, 85\% of Pakistan's population are unbanked (Ahmad, 2014). These people are totally financially excluded (Devlin, 2009) and may experience vulnerability (Wang and Tian, 2014). Vulnerability is a tendency to be wounded; it is vulnerability to detriment of different sorts (Ståsett, 2007, p.51). Those who lack access to financial services are exposed to harm (Cartwright, 2011; Kempson and Collard, 2012) that explains their experience of vulnerability. Researchers have usually focused on consumer vulnerability in the context of micro-credit from private and informal money lenders (e.g. Palmer and Conaty, 2002; Mariwah, 2012). However, previous studies have rarely examined the unbanked consumers from the perspective of broader vulnerability. Contemporary consumers need access to banking services for paying off their bills and purchases, for obtaining loans, or to save and transfer money securely (Kempson and Collard, 2012). Thus, those who lack access to a bank account may experience vulnerability in managing their day to day finances.

Low-income groups are at a high risk of facing financial exclusion (Kempson and Whyley,1999; Carbo et al., 2007). While inequality is common in various areas of consumption, studies on consumption and marketing rarely mention financial inequality (Ekström and Hjort, 2009). Countries with the highest levels of income inequality have higher levels of financial exclusion (Kempson, 2006). Low-income consumers are commonly financially excluded resulting in them to face inequality in the marketplace. The World Bank categorizes developing countries' inhabitants earning below USD4,000 per annum in a low-income group (Ahmad, 2013). Low-income consumers often encounter difficulties in accessing basic services including financial services (Lee and Murie, 1999). Therefore, this study focuses on the vulnerability of unbanked low-income individuals. The study is carried out in Pakistan, where a significant proportion of the population lives on less than USD4,000. Low-income people are separate from the bottom of the pyramid consumers (Viswanathan et al., 2010; Jebarajakirthy et al., 2015) who live on USD1.25 a day (World Bank, 2008).

The study aims to delineate means to improve the well-being of low-income consumers by suggesting routes to aid financial inclusion of the disadvantaged population. The objective of this paper is to unfold the areas of vulnerability due to financial exclusion. It examines how low-income unbanked consumers in a developing country experience vulnerability and how they encounter it in their daily life. The study contributes to the literature of financial exclusion by providing new insights from a developing country context where consumer related issues are rarely explored. Second, it contributes to understanding consumer vulnerability by showing the critical issues faced by unbanked consumers. Thus, the study provides insights into the ways that low-income consumers encounter vulnerability in their everyday lives. 


\section{Consumer vulnerability}

Previous studies have taken different approaches to consumer vulnerability. While there is no consensus about the definition of vulnerability it usually refers to consumer detriment which is caused by internal and external factors (e.g. Smith and Cooper-Martin, 1997; Baker et al., 2005). Internal factors of vulnerability are linked to the personal characteristics of individuals such as low-income (Hamilton and Catterall, 2005) and low literacy or illiteracy (Adkins and Ozanne, 2005). External factors are beyond individuals' control (Baker et al., 2005, p.130), such as marketplace discrimination, which adversely affects well-being of underprivileged consumers (Walsh, 2009). For instance, Smith and Cooper-Martin (1997, p. 4) define vulnerable consumers as 'those who are more susceptible to economic, physical, or psychological harm in, or as a result of, economic transactions because of characteristics that limit their ability to maximize their utility and well-being'.

Baker et al. (2005) underscore that consumer vulnerability is multidimensional and contextual because anybody can feel vulnerable in different situations, which do not represent a permanent state. An individual may feel vulnerable when she/he is unable to make an important purchase because an internal or external factor impedes it. This definition also implies that financially excluded consumers may experience marketplace vulnerability (Wang and Tian, 2014) as different internal and external factors impede their financial inclusion (Leyshon and Thrift, 1995; Kempson and Whyley, 1998;1999; Matin et al., 2002; Kempson, 2006; Carbo et al., 2007). Moreover, financial exclusion could be a relatively permanent state for the unbanked consumers in many developing countries as policy response to combat financial exclusion issue is rather passive. This complacency is evidenced by high financial exclusion rates in several developing nations (Honohan, 2008).

The low-income and illiterate are likely to experience vulnerability (Burden, 1998) and require additional support in the marketplace (Brennan, 2006). However, there is no empirical evidence that the individual characteristics are the sole basis for vulnerability (Baker et al., 2005, p.130), but vulnerability can also be caused by a person's environment. People may feel vulnerable because of barriers that restrain them from participating in society (Baker and Mason, 2012). The external factors that cause vulnerability are beyond individuals' control and include stigmatisation and repression, distribution of resources, physical elements, logistical elements, and other environmental conditions, such as economic, social, and political upheaval or violence. These factors contribute to power imbalances in exchange relationships that disfavour consumers (Baker et al., 2005, p.130). Hill and Stamey (1990) note that homeless people's internal characteristics make them vulnerable, whereas external factors such as societal and structural conditions contribute to the circumstances in which they live because those factors are beyond their control.

Smith and Cooper-Martin (1997) distinguish between perceived and actual vulnerability. Perceived vulnerability is present when others consider an individual vulnerable (i.e. based on demographical characteristics or environmental circumstances), but the 
individual is either not vulnerable or does not admit her/his vulnerability. Conversely, actual vulnerability occurs when vulnerability is experienced by consumers. Actual vulnerability can be recognised and understood only by listening to and observing consumers' experiences. Studying consumer vulnerability from an environmental and demographic standpoint is problematic because doing so casts vulnerability as both onedimensional and permanent (Baker et al., 2005; Baker, 2009). Nevertheless, this view of consumer vulnerability is helpful for both policy makers and marketing practitioners to identify customers or groups of customers who need extra assistance (Baker, 2009). It is real vulnerability that should be addressed by public policy makers and marketers (Baker et al., 2005, p128). According to this view of actual vulnerability, both internal and external factors render a person vulnerable in the marketplace (Baker et al., 2005). For instance, consumers with low incomes (internal factor) are discriminated against by the financial services providers' policies (external factor) (Matin et al., 2002).

In the context of financial services, different internal and external factors trigger financial exclusion (Leyshon and Thrift, 1995; Kempson and Whyley, 1998;1999; Hogarth, and O’Donnell,2000; Matin et al., 2002; Kempson, 2006; Carbo et al., 2007) rendering the financially excluded individuals vulnerable (Cartwright, 2011; Wang and Tian, 2014). However, actual vulnerability (Baker, et al., 2005) of the unbanked individuals arises when they encounter the difficult circumstances in their everyday lives without having workable means to cope with the detriment. In light of the above literature, we understand that financially excluded individuals are vulnerable consumers. Our empirical study seeks more thorough understanding of unbanked individuals' experiences of vulnerability in the context of financial services.

\section{Financial exclusion}

Financial exclusion is a term that refers to people who lack access to financial products (Kempson and Whyley, 1999), in particular, to essential banking services (Kempson and Whyley, 1999; Panigyrakis et al., 2002). An individual lacking access to transaction banking, savings, credit or insurance is considered financially excluded (World Bank, 2005). In extreme cases, people are completely excluded from the mainstream financial system (Devlin, 2009) and have no access to any financial services in an appropriate form (Panigyrakis et al., 2002).

Exclusion from the basic services aggravates both financial poverty and stress of some customer groups (Speak, 2000). People without a bank account encounter problems when cashing cheques and need to get their cheques cashed from third parties names (e.g. companies) who charge commissions for this service (Kempson and Whyley, 1998). Financial exclusion can also adversely affect self-esteem and lead to deprivation of social connections. In some instances paying through cash can raise suspicion in others' minds that the money is stolen, which may also result into humiliation and lower self-esteem (Collard and Kempson, 2005). Households without a bank account in the UK usually pay more for basic household services (Kempson and Whyley, 1999). For instance, people

paying their utility bills in cash pay more per year than people paying through direct debit (Kempson and Whyley, 1998;1999). Similarly, unbanked people face difficulties in 
accepting a job offer because the employer usually uses a bank account for salary payments (Kempson and Whyley, 1999). People keeping savings in cash in their homes are vulnerable to robbery (Kempson and Whyley, 1999) and can not get interest on their savings (Kempson et al., 2005).

Likewise, financially excluded people lack access to short-term credit and often use highcost private or illegal moneylenders (Wallace and Quilgars, 2005; Kempson and Whyley, 1999). Usually, the relationships among customers and illegal money lenders rest on fear and threats (Ellison et al., 2006). These moneylenders charge very high interest rates, which also increases economic stress of low-income people (Herbert and HopwoodRoad, 2006).

A vast majority of the Pakistani population lives without a bank account. Many unbanked consumers utilize mobile money services (Morawczynski, 2009), and cope with the inefficiencies of financial service providers (Flood et al., 2013). They can receive and transfer funds, purchase goods and pay bills through mobile money service. However, only 5\% of Pakistanis use mobile money services (Kironget, 2014). Likewise, only 2\% of the poor in Pakistan have access to microfinance services, which is significantly less than neighboring countries (Kironget, 2014). Similarly, discrimination of financial institutions against poor (Matin et al., 2002; Leyshon and Thrift, 1995) also impedes low-income consumers' financial inclusion. Moreover, Kempson and Whyley (1998) note that in the UK, some people of Pakistani and Bangladeshi origin face religious obstacles to banking because conventional banking practices are prohibited under Islamic law. In a Muslim country such as Pakistan some people may resist opening a bank account due to religious reasons. Nevertheless, all of the above factors may render the unbanked vulnerable in the Pakistani marketplace.

\section{Methodology}

This study employed the semi-structured interview method to collect data from disadvantaged consumers in Pakistan, to explore the experiences of completely financially excluded individuals (cf. Miles and Huberman, 1994, p.10). We recruited 28 interviewees from four lower-social-class areas in Rawalpindi and Islamabad. The criterion for selecting the participants was that they did not have a basic bank account. We employed purposeful sampling, which entails the recruitment of informants who could provide detailed information about the studied issues. Four participants who had been informed about the participant qualification criterion helped to recruit participants in

their respective neighbourhoods. The sample included 10 females and 18 males, most of whom worked in various low-income professions. Moreover, eight participants were local residents and 20 were rural migrant workers in Rawalpindi and Islamabad. Participants' monthly incomes ranged from 7,000 to 20,000 Pakistani rupees (70-200 USD). Moreover, most of the participants either were illiterate or had left school in their early years. Table 1 displays the participants’ demographic characteristics.

Place Table 1 here 


\section{Data collection}

The interviews were conducted in various locations, including homes, small restaurants, and shops during their less busy hours. All of the participants volunteered to participate in the study; they were provided with monetary incentives. University ethical guidelines were followed in working with the participants. The participants were provided with an information sheet and a consent form before the interview. Given that most of participants were either less literate or illiterate, the information sheet and consent form were explained to them orally before the interview. Moreover, the participants received assurances of confidentiality and anonymity. The interview guideline included questions about different factors that hinder individuals from opening a bank account and about the adverse consequences of financial exclusion. Further, the guide included questions about methods used by the participants to transfer money, save money and obtain short-term credit as well as demographic questions.

During the interviews, the wording and sequencing of the questions were kept flexible to accommodate both the situation and the interviewees' characteristics. A non-directive questioning method was employed to encourage the informants to discuss the issues in detail (Elliott and Jankel-Elliott, 2003). Twenty-five interviews were conducted in Urdu and three in Punjabi. All interviews were conducted by the first author, and audio recorded with the participants' consent. The interviews were conducted until we reached the theoretical saturation point, that is, the point at which the informants are providing no new information (Flick, 1998). The length of these interviews ranged from 22 minutes to one hour with an average of 33 minutes. Tape-recorded interviews of more than 15 hours were transcribed, resulting in 474 hand-written A4 pages. Pseudonyms are used to maintain interviewees' anonymity and confidentiality (Eriksson and Kovalainen, 2008).

Data analysis

Thematic analysis was performed to identify, analyse and report patterns within data (Braun and Clarke, 2006). The accuracy of the transcripts was re-checked by listening to the audio records many times, which is considered an important step in data analysis that takes an interpretive, qualitative approach (Bird, 2005). After reading and familiarising ourselves with the data, initial codes were identified within the data set. After producing a list of codes, a broader analysis was performed to identify the potential to combine codes with different themes. This process helped us to identify the main themes which were initially reviewed at the coded data extract level; subsequently, they were reviewed at the entire data set level. We then attempted to explain the meaning of each theme and identified which parts of the data were related to each theme. Themes were given names that explain their relevance to the research question (Braun and Clarke, 2006).

\section{Findings}

Based on the analysis of the data and literature review, we find that vulnerability of financially excluded consumers in a developing country originates from various external and internal factors, and different subgroups experience vulnerability in different ways. 
Moreover, unbanked consumers experience vulnerability in the shape of negative consequences of personal, economic and social lives.

The findings portray that unbanked consumers experience vulnerability at varying degrees and in various ways. Local residents had opportunities and some degree of control: they rarely transferred money to other destinations and usually acquired loans from their social contacts which made them less vulnerable as compared to the rural migrant workers. Nevertheless, they experienced vulnerability in other ways. For instance, they faced adverse consequences such as fear of robbery while keeping savings at home, difficulties in saving money, time wastage during bill payments; lack of business opportunities and damaged relationships. The unbanked rural migrant workers were particularly vulnerable due to the lack of opportunities. They transferred money regularly to villages in different ways, usually acquired loans from informal lenders and saved money in different manners which often resulted into their detriment of different sorts (e.g. costly and risky transporting money to another village or town centre).

Male and female participants experience similar types of vulnerability in their attempt to save, to acquire short-term credit and in utility bills payments. Differences were observed related to external factors. Except two, all males transferred money frequently to their families in villages and to other destinations. As regards female participants, half of them had never transferred money to other destinations, others transferred money irregularly, and they rarely transferred money to their own parents or to family members. This is connected to the cultural context of Pakistan, where it is male members' responsibility to financially support their parents and sometimes extended families.

The majority of participants were illiterate or less literate, i.e. school leavers. However, a few were educated to high school or college level and one completed an undergraduate degree. Similar patterns in experiencing vulnerability were manifested in terms of savings, money transfers and bills payments in literate and illiterate groups due to lack of opportunities and control. However, none of the seven literate participants acquired loans from the informal money lenders due to their knowledge about the detriment resulting from this. Moreover, some illiterate and low-literate participants had little information about the banks and benefits of having a bank account. Conversely, all educated participants had rather good knowledge of banks and the ways they can improve their well-being. Participants of different ages transferred and saved money, paid utility bills, required short term credit. In particular, older aged participants did not go to banks because their bills were paid by their family members. Lastly, participants employed by informal employers and self-employed participants reported almost similar patterns of detriment for being unbanked. However, a few participants who were self-employed or doing their own small business reported to have lack of business opportunities because some prospective clients may only pay through cheques or bank transfer. Further, a few self-employed workers also reported to feel embarrassed when their clients offered them to pay them through bank.

This study shows that external factors are major contributors in making the low-income consumers unbanked and experience vulnerability. External factors were related to socio- 
cultural environment such as family members' disapproval to open a bank account and religious reasons. In addition, low-income consumers face barriers at bank staff, bank policy and regulator level. Participants presented accounts that when attempting to open a bank account banks staff gave them inadequate information, wasted their time, passed discriminatory statements and provided poor service. At bank policy level, most banks tend not to expand their branch networks to geographically remote areas. Most of Pakistan's population lives in rural areas, thus a large proportion of the rural population lacks access to bank branches. The participants in this study were urban residents who did not face significant geographical barriers to banking. For instance, in the UK context only $1 \%$ of the unbanked households reported that non-existence of a bank branch nearby their home is a reason of their financial exclusion (Kempson \& Whyley 1999). Moreover, regulatory barriers hinder low-income consumers from opening, for example the requirement of an initial deposit from the new customers, and documentation requirements for opening a bank account.

Salaries paid in cash impede some low-income consumers to open bank account. Our study findings are dissimilar to Kempson and Whyley (1999) underscoring difficulties for unbanked people to accept a job offer because employers pay salaries in banks in the UK. Pakistan has a significant size of informal economy and employers generally pay salaries in cash and they usually do not issue any employment letter/contract to employees. Consequently, they cannot fulfill the documentation requirements for bank account opening.

In the following section we discuss the themes that illustrate how the participants described their experience of vulnerability.

\section{Personal consequences}

The participants reported personal consequences of being unbanked as fear of robbery, time wastage, intimidation from lenders and sense of deprivation.

The data indicates that unbanked individuals face the fear of robbery in several ways. Participants reported to keep their money in boxes and in other safe places within their home not just for saving purposes but for emergency use too. Meanwhile, they reported to have serious concerns about the safety of their savings kept in home. The feeling of fear of robbery was linked in some cases to the poor law and order situation prevalent in the country. In other cases, the fear was due to participants close relatives, who were looted. Accordingly, a bank account was considered an important aid in achieving security and avoiding fear.

Opening a bank account has this benefit that if I have deposited money that will remain safe (Noor, 32).

Further, those individuals who took salaries in cash from their employers also reported fear of robbery. Participants felt helpless and raised the question: if they lose their 
savings, how will they survive? A male participant who works as a salesman in a shop and whose salary is paid in cash expresses his fear of robbery as follows:

Often I am afraid that some thing bad may happen. Some one might snatch money from me. This is the only money which I have. If this is snatched then what will I do?(Shan, 26).

Some participants reported to handing over savings to their trusted social contacts such as family member or friend and requesting money whenever they needed. Meanwhile, other participants expressed their apprehension that the person who minds their money may keep it. Participants who had transferred money to their families in villages through drivers reported fear of robbery on the way. Many participants were financially supporting their families who were residing in villages. These people expressed a genuine concern of their families' economies and welfare.

Financially excluded individuals necessarily have to go to bank branches or other outlets to pay their utility bills in cash. This often results in wasted time and exhaustion because of long queues. The low-income consumers who are unbanked mostly rely on informal work and do not enjoy paid holidays. Time wastage during working hours implies that they either lose proportion of their daily wages or are reprimanded by their employers in different ways. This cost is due to both their working in low paid or informal jobs and banks bills payment procedures. Thus, the internal and external factors interplay causing the low-income participant vulnerability. A maid explains her concerns as follows:

There are long queues. The entire day passes, and then we have to listen to comments from people where we work about arriving late. 'We need you, guests are coming.' We listen to comments, then time is wasted... It is tiring, but what we can do? We are helpless (Bano, 36).

Moreover, a number of participants reported that bank staff had wasted their time when they tried to open a bank account. With little or no literacy skills to understand bank account opening requirements and bank staff's poor service, consumers have to spend time to get the task done. A participant who visited a bank to open an account was unable to do so and had to go to the bank several times, mainly because of documentation requirements. He reported that he was not given any immediate candid advise by the bank's front desk about his eligibility to open a bank account.

They should have told me very first day that your account will not open. They told me this on third day. I kept going there for three days (Zain, 30).

Numerous participants reported emotional distress after acquiring loans from informal sources. While participants in general disliked taking a loan from informal lenders many did so because they were unable to acquire the desired amount of loan from their social contacts. The restricted income led in some cases to difficulties in paying back the loan instalments. Thus, both poverty and external factors i.e. lack of social support and informal lenders aggressive behaviour render the unbanked vulnerable. Some participants 
experienced intimidating behaviour from moneylenders. They reported that the lenders insult them in front of neighbors and other people in the event of delay/ non-payment of instalments. They also face threats from lenders that their home movables could be confiscated. The following excerpt explains this dilemma.

If we do not pay our instalments on time, they come to our home. Then, they say that they will take our movables. They will take our things. They will take our TV with them. They do this if we do not repay them on time (Nori, 40).

Financial exclusion resulted in a sense of deprivation. It stemmed from poverty and the experience of bank staff's discrimination against low-income customers. Some participants elucidated that low-income consumers are not treated on equal grounds by the bank staff. They are aware that they have to face detriment and they felt that they are unwanted consumers in financial services due to their poor economic circumstances. A sense of deprivation arose from the belief of being unbanked due to poverty. A female participant who can not open a bank account explains it as follows:

I really wish to open a bank account, I also want that I have an ATM card through which I withdraw money but I can not do this due to lack of money (Izza, 55).

\section{Economic consequences}

The unbanked consumers face adverse economic consequences in shape of difficulties in saving money, high cost money transfer and lack of business opportunities.

Almost all participants reported having saved money for emergency use. However, they demonstrated varying degree of self-discipline to saving. For instance, those with higher self-discipline could keep savings at home but those who lack this skill reported difficulties in saving money without a bank account as they are tempted to spend money on unnecessary purchases. Participants saved money for a specific need in mind or for emergency use such as doctor fee in the event of illness. Lack of access to a bank account impeded some participants' saving endeavours. The following quote explains this.

There is a disadvantage if you save one thousand rupees. If you deposit them in account, then they are saved. You can save another thousand, but if you do not have a bank account, then you might say, 'I have one thousand Rupees, let me spend it' (Malik, 47).

Sending money to families in villages through SMS-based money transfer facilities offered by Pakistani telecom companies was a common practice among the participants. However, the high service charges force the low-income consumers to compromise another need to pay for money transfers. Some participants felt being exploited by SMS money transfer service providers due to their financial exclusion. They were aware that money transfers through banks cost significantly less than SMS money transfer facilities, which elucidates their helplessness. Using SMS-based money transfer facilities was opposed due to the high costs, and some participants preferred to use lorry drivers for transferring money to their respective villages. Although considered unsafe by 
participants but they preferred this option over SMS-based money transfer in order to avoid the economic detriment. When money transfer via the truck driver option was not accessible, participants also utilised SMS-based money transfers. A male participant elucidates his concerns about the high costs of money transfer and feelings of helplessness as follows:

This is 'easy paisa'-if I have to send 4,000 rupees, they take 240 rupees. This is a loss. I could have purchased a meal for my family with that money (Malik, 47).

Financial exclusion can result in the lack of business opportunities. Some self-employed participants reported experiencing this type of detriment as they were unable to get work from high rate paying clients. Due to extremely high rate of financial exclusion among low-income groups in Pakistan these consumers may not find an individual within their social network, who could help them to cash their cheque. This exacerbates their financial detriment and experience of vulnerability. A participant who is a self-employed boreworker explains that being financially excluded, he cannot take high-rate work from firms because they pay through cheques or into bank accounts:

I do not have a bank account, so I cannot take high-rate work. I cannot take government work or any company work because all of the companies pay with cheques (Jnai, 43).

\section{Social consequences}

The unbanked consumers face adverse social consequences in form of embarrassment and damaged relationships.

Those who lack access to financial services are often excluded in other ways, and financial exclusion often strengthens other aspects of social exclusion (FSA, 2000, p. 7). Although in Pakistan a vast majority of people lack access to financial services, it results in embarrassment for some unbanked individuals. A participant who interacted with a client for money payment explained that he felt embarrassed when his client learned that he did not have a bank account.

Once, I did some work and they had to pay me some money. Then one of his brothers, I think he was in Karachi... he rang and asked me where I had my bank account. I said that I did not have a bank account, and he laughed and said, 'you do not have a bank account.' I felt ashamed (Jani, 43).

Those with bank accounts can take loans from banks but unbanked consumers lack access to short-term finance. Consequently, they usually rely on informal money lenders or social contacts such as relatives and friends. A number of participants reported taking loans from their close relatives and friends whereas some reported having damaged relationships as they were not able to return the loan in time. A maid explains how her husband took a loan from his brother but failed to return it due to economic problems. Consequently, the relationship with sister in-law became sour as she demanded the money back. 
His sister in-law was saying too many things but his brother understands that he is my brother...Then he took his brother outside and said that you give money back in two months (Nelo, 25)

Some participants who were keeping savings at home feared damaging their relationships with their close relatives. These relatives usually know that they have kept money at home. They cannot decline if their close relatives ask for a loan, and problems arise if their relatives do not repay their loans within an agreed timeframe and agreed lump sums.

To conclude, vulnerability and exclusion is experienced in various personal, economic and social spheres of the individuals' lives. Table 2 displays the internal and external factors that influence vulnerability in the different domains.

Place Table 2 here

\section{Discussion and conclusions}

While previous studies have not explicitly studied unbanked consumers' vulnerability, the major contribution of this study is providing insights into the actual vulnerability (Baker, et al., 2005) of the unbanked in a developing nation context. Financial exclusion is present in developed countries, but at a very low rate. The magnitude of problems experienced by financially excluded individuals in a country such as Pakistan is far greater and different than in developed countries. Therefore, the adverse consequences of financial exclusion highlighted by the previous researchers in the developed world context significantly differ from this study's findings. Widespread illiteracy, poverty and social, economic and organisational injustice prevent financial inclusion, which leads to consumers experiencing of vulnerability to different forms of detriment. The disadvantaged position of the unbanked as compared to the mainstream financially included consumers leads the disadvantaged to experience vulnerability. The results portray that low-income unbanked individuals suffer personal, economic and social detriment.

Participants suffer personal detriment in the form of fear of robbery, intimidation from lenders, time wastage and a sense of deprivation. Consistent with previous research (Kempson and Whyley, 1999) this study finds that people keeping savings in cash in their homes are susceptible to robbery. However, this type of vulnerability is expected to be multiple in a developing country like Pakistan because of the problematic law and order situation. Moreover, due to higher rates of financial exclusion people carrying substantial money in their pockets such as cash salaries, handing their savings to others and transferring money through drivers also encounter threat of robbery. The informal sources of finance and informal lenders are major sources of intimidation which influences consumers' well-being. Pakistan has an extremely high rate of financial exclusion (Honohan, 2008) and only $2 \%$ of the poor have access to formal microfinance services (Kironget, 2014). These circumstances make the majority of low-income vulnerable when they need a loan. Likewise, those who are unbanked may waste their 
time while paying their bills. Previous research highlights in the UK context that unbanked people paying utility bills in cash pay more per year than people paying through direct debit (Kempson and Whyley,1998;1999). This is not the case in Pakistan, as cash transactions are used by the majority. Collard and Kempson (2005) found that paying in cash also raises suspicion in others' minds that the money is stolen which may also result into a state of humiliation and lower self-esteem for financially excluded individuals. Yet again, this is not the case in Pakistan as vast majority of transactions are completed in cash because online transfers and plastic money are not widely used. Lastly, unbanked consumers felt deprived as banks discriminate against them due to their poverty. To conclude, these adverse consequences are either multiple or differ significantly from developed countries because of widespread financial exclusion and lack of the socio-economic development in developing countries such as Pakistan.

Financially excluded consumers undergo economic detriment in the shape of difficulties in saving money. While lack of business opportunities is suffered by some unbanked consumers it is not expected to be widespread issue amongst the unbanked in Pakistan. In many developed countries it would be extremely difficult to work as a self employed person or run a small business without a bank account because of the formal economy. In Pakistan, many self-employed and small businessmen are unbanked and manage their business transactions without formal bank accounts as the majority of transactions are completed in cash especially in business to consumer market. However, those who lose their clients due to a bank account requirement suffer this detriment in Pakistan too.

Moreover, low-income consumers are at a disadvantage in the marketplace and often pay more for basic necessities (Caplovitz, 1967; Goodman, 1968) and pay high charges for money transfers through SMS services. Mobile financial services provide opportunities to unbanked individuals to access financial services in developing countries (Morawczynski, 2009) and in Pakistan these services are mainly targeted to low-income people, but in order to improve their well-being, the services' prices should be affordable. This implies that sometimes the financially excluded individuals can be exploited.

Lastly, the unbanked suffer social detriment in form of embarrassment and damaged relationships. In developed countries everyone is expected to have a bank account and being unbanked may strengthen other aspects of social exclusion (FSA, 2000, p. 7). However, many unbanked consumers in Pakistan may not feel embarrassed because of widespread financial exclusion. Low-income consumers usually do not have banked people in their social network. Social detriment of unbanked consumers may arise when interacting with banked individuals for completing transactions through banks. While this disadvantage is suffered by low-income individuals, it may be more severe and widespread amongst the unbanked in a developed country than in Pakistan. Damaged relationships could be more severe consequence from being unbanked in collectivistic cultures such as Pakistan. It is expected that an individual will help other group members when they are in any need. Defying this social norm may result into bad reputation and damaged relationships in the group which a person may not afford (Ahuvia, 2002). These social norms make it difficult for a person to decline a loan to his/her close relative. 
Different internal and external factors contribute to financial exclusion which render the unbanked vulnerable. However, these factors may vary country to country (Marshall, 2004). A vast majority of the participants outlined the benefits of having a bank account. They wanted to open a bank account but failed to do so either due to their poverty or different cultural and institutional barriers. This portrays that they want to escape from the vulnerability they experience due to financial exclusion. Conversely, a few participants who had no information about banks did not recognize any benefits of having a bank account. They may not feel vulnerable as they are not aware that bank account can improve their wellbeing. Thus, actual vulnerability may be related to consumers' awareness and knowledge about the opportunities.

Unbanked individuals lack control over their personal and environmental circumstances, resulting in personal, social or financial suffering. Baker et al. (2005, p. 134) maintain that vulnerability occurs when barriers prohibit control and prevent freedom of choice, and that a lack of personal control is a key element of the experience of consumer vulnerability. Correspondingly, this study finds that the negative consequences of financial exclusion are related to the lack of control over the personal and environmental circumstances. Low-income consumers often face personal, cultural, institutional and structural barriers to banking (Leyshon and Thrift, 1995; Kempson and Whyley, 1998; 1999; Matin et al., 2002; Kempson, 2006; Carbo et al., 2007).

In short, financial exclusion impedes the well-being of low-income consumers in several ways which warrants effective policy measures to combat large scale financial exclusion. Financial services are the basic need of contemporary consumers and lack of their supply can cause consumer costs and vulnerability (Cartwright, 2011). In developing countries, such as Pakistan, financial exclusion is extremely common, and the low-income groups, in particular, are affected by the negative consequences. There are, however, possibilities for public policymakers and banks to decrease the impact of financial exclusion.

\section{Managerial and public policy implications}

Regulators and major banks have responded to the issue of financial exclusion passively although it can be considered as their responsibility to facilitate financial inclusion of the unbanked so that consumers can avoid the hindrances caused by financial exclusion and their well-being is improved. Unlike in the developed world, developing nations have few consumer protection agencies that can force institutions to behave responsibly. This potentially results in the exploitation of low-income consumers in many consumption spheres including the financial services. We propose the following policy implications for the financial inclusion and well-being of the low-income unbanked consumers.

Banks are in a key position to serve different consumer groups, and therefore we propose that bank regulators formulate policies that facilitate low-income consumers' financial inclusion. At the time of data collection for this study in 2014, banks had a strict documentation requirement to open a bank account. Recently, however, banks in Pakistan have relaxed these requirements for the low-income consumers, so that a bank account could be opened by providing an identity card and filling in a form. Although this 
regulatory change helps financial inclusion of the low-income, there is still need for proactive policies for facilitating the financial inclusion of the less-privileged segments of the society. Banks could also consider opening more branches in rural areas or using other policies to provide accessible banking to rural population. Second, banks should launch educational programmes to create public awareness about the importance of having a bank account. Third, the charges of mobile money transfer in Pakistan are significantly higher than those charged by the banks. Considering the economic circumstances of the low-income target market of the mobile money transfer services, the firms should reconsider the money transfer fees. Further, mobile money services offer various benefits, for instance, people can save money and pay their utility bills through their mobile money accounts. Savings through these accounts offer some profit on saved money, and their use could be an alternative to informal saving methods for the unbanked. While almost $90 \%$ of the poor and rural population have access to a mobile phone and SIM card in Pakistan mobile money registration and use are extremely low (Kironget, 2014). Consumer education is vital particularly in innovative services such as M-finance (Anong and Kunovskaya, 2013). This implies that the mobile money service providers should revise their marketing strategies and educate the target market about the benefits of using mobile money accounts over the informal ways of managing finances. Lastly, the lack of access to microfinance services leads to the exploitation of the poor by the informal money lenders. Therefore, to protect the low-income unbanked individuals both microfinance banks and NGO's providing microfinance should increase their level of operations. They also should educate the vulnerable people about the repercussions of acquiring loans from informal lenders.

\section{Limitations and future research guidelines}

This research focuses on low-income unbanked consumers, but the fact that $85 \%$ of the Pakistani population remains unbanked implies that other social classes include unbanked individuals. Therefore, future studies could examine whether and how the experience of vulnerability as a result of financial exclusion varies amongst different social classes. Second, this study does not incorporate the bankers' perspective about the higher rates of financial exclusion in Pakistan and challenges they face to serve this large part of population. Future research could investigate bankers' perspectives on institutional barriers to banking at the levels of bank staff, bank policy and bank regulators to unfold the challenges and difficulties related to the financial inclusion of poor. Lastly, given that the majority of Pakistan's population is financially excluded, future research could address the coping strategies employed by financially excluded individuals.

\section{References}

Adkins, N. R., \& Ozanne L. J. (2005) The low literate consumer. Journal of Consumer Research, 32, 93-105. 
Ahmad, A. (2013) Middle class shrinking rapidly. The News. [WWW document]. URL http://www.thenews.com.pk/Todays-News-3-203314-Middle-class-shrinking-rapidly (accessed on November 26th, 2014).

Ahmad, M. (2014) Financial exclusion a new kind of apartheid. The News. [WWW document]. URL http://www.thenews.com.pk/Todays-News-3-269454-Financialexclusion-a-new-kind-of-apartheid (accessed on November 27th, 2014).

Ahuvia, A. C. (2002) Individualism/collectivism and cultures of happiness: A theoretical conjecture on the relationship between consumption, culture and subjective well-being at the national level. Journal of Happiness Studies,3, 23-36.

Anong, S. T., \& Kunovskaya, I. (2013) M - finance \& consumer redress for the unbanked in South Africa. International Journal of Consumer Studies, 37, 453-464.

Baker, S. M. (2009) Vulnerability \& resilience in natural disasters: A marketing and public policy perspective. Journal of Public Policy \& Marketing, 28, 114-123.

Baker, S. M. \& Mason, M. (2012) Toward a process theory of consumer vulnerability \& resilience: Illuminating its transformative potential. In: D. G. Mick, S. Pettigrew, C. Pechmann, \& J. L. Ozanne (Eds.), pp. 543-564. Transformative consumer research for personal and collective well-being, Routledge, New York, USA.

Baker, S., Gentry, J. W., \& Rittenburg, T. L. (2005) Building understanding of the domain of consumer vulnerability. Journal of Macromarketing, 25, 128-139.

Bird, C. M. (2005) How I stopped dreading \& learned to love transcription. Qualitative Inquiry,11, 226-48.

Braun, V., \& Clarke, V. (2006) Using thematic analysis in psychology. Qualitative Research in Psychology, 3, 77-101.

Brennan, C. (2006) Empowering vulnerable consumers in the KBE: Taking forward policy, knowledge and a new alliance for consumer education. Paper presented at Institute for advanced studies workshop, Consumers and the knowledge based economy, Lancaster University, Lancaster.

Burden, R. (1998) Vulnerable Consumer Groups: Quantification and Analysis. Office of Fair trade, Research Paper15, London.

Caplovitz, D. (1967) The Poor Pay More, Consumer Practices of Low-Income Families. The Free Press, New York.

Carbo , S., Gardener, P.M.E. \& Molyneux, P. (2007) Financial Exclusion in Europe. Public Money \& Management, 27, 21-27. 
Cartwright, P. (2011) The vulnerable consumer of financial services: Law, policy \& regulation. In financial services research forum. University of Nottingham, Nottingham, UK.

Collard, S. \& Kempson, E. (2005) Affordable Credit: The Way Forward. Joseph Rowntree Foundation, York, UK.

Demirgüç-Kunt, A. \& Klapper, L. F. (2012) Measuring financial inclusion: The global findex database. World Bank Policy Research Working Paper (6025).

Devlin, F. J. (2009) An analysis of influences on total financial exclusion. The Service Industries Journal, 29 ,1021-1036.

Ekström M. K. \& Hjort, T. (2009) Hidden consumers in marketing - the neglect of consumers with scarce resources in affluent societies. Journal of Marketing Management, $25,697-712$.

Elliott, R. \& Jankel-Elliott, N. (2003) Using ethnography in strategic consumer research. Qualitative Market Research: An International Journal, 6 , 215- 223.

Ellison, A., Collard, S. \& Forster, R. (2006) Illegal lending in the UK, Policis \& Department for Trade \& Industry, London.

Eriksson, P. \& Kovalainen, A. (2008) Qualitative Methods in Business Research. Sage, Los Angeles.

Flick, U. (1998) An Introduction to Qualitative Research. Sage, London.

Flood, D., West, T. \& Wheadon, D. (2013) Trends in mobile payments in developing and advanced economies. Reserve Bank of Australia, Australia.

FSA. (2000) In or Out? Financial Exclusion: A Literature \& Research Review. Financial Service Authority, London.

Goodman, C. S. (1968) Do the Poor Pay More? Journal of Marketing, 32 ,18-24.

Hamilton, K. \& Catterall, M. (2005) Towards A Better Understanding of the LowIncome Consumer. Advances in consumer research, 32, 627-632.

Herbert, T. \& Hopwood-Road, F. (2006) Banking Benefits: CAB Evidence on Payment of Benefits into Bank Accounts. Citizens Advice, London.

Hill, R. P. \& Stamey, M. (1990) The homeless in America: An examination of possessions \& consumption behaviors. Journal of Consumer Research, 17, 303-321. 
Hogarth, J. M. \& O’Donnell, K. H. (2000) If you build it, will they come? A simulation of financial product holdings among low-to-moderate income households. Journal of Consumer Policy, 23, 409-444.

Honohan, P. (2008) Cross-country variation in household access to financial services. Journal of Banking \& Finance, 32, 2493-2500.

Jebarajakirthy, C., Lobo, A. \& Hewege, C. (2015) Enhancing youth's attitudes towards microcredit in the bottom of the pyramid markets. International Journal of Consumer Studies, 39, 180-192.

Kempson, E. (2006) Policy level response to financial exclusion in developed economies: lessons for developing countries. The Personal Finance Research Centre University of Bristol, Bristol.

Kempson, E. \& Collard, S. (2012) Developing a Vision for Financial Inclusion. Friends Provident Foundation, Dorking, UK.

Kempson, E., McKay, S. \& Collard, S. (2005) Incentives to Save: Encouraging Saving Among Low-income Households Final Report on the Saving Gateway Pilot Project. HM Treasury, London.

Kempson, E., \& Whyley, C. (1998) Access to Current Accounts. British Bankers Association, London.

Kempson, E. \& Whyley, C. (1999) Kept out or opted out? Understanding and combating financial exclusion. Policy Press, Bristol.

Kironget, L. (2014) Pakistan mobile money gap analysis, USAID.

Lee, P. \& Murie, A (1999) Literature Review of Social Exclusion. The Scottish Office Central Research Unit, Edinburgh, Scotland.

Leyshon, A. \& Thrift, N. (1995) Geographies of financial exclusion: financial ab\&onment in Britain and the United States. Transactions of Institute of British Geographers, 20, 312-341.

Leyshon, A., Thrift, N.J. \& Pratt, J. (1998) Reading financial services: texts, consumers, and financial literacy, Environment \& Planning D: Society \& Space, 16, 29-55.

Mariwah, S. (2012) Shylock VS. Antonio: Informal money lending in rural communities in the Jaman north district, Ghana. Journal of Sustainable Development in Africa, 14,150161. 
Marshall N, J. (2004) Financial institutions in disadvantaged areas: a comparative analysis of policies encouraging financial inclusion in Britain and the United States, Environment and Planning, 36, 241-261.

Matin, I., Hulme, D. \& Rutherford, S. (2002) Finance for the poor: from microcredit to microfinancial services. Journal of International Development, 14, 273-294.

Miles, M.B. \& Huberman, A.M. (1994) An Expanded Sourcebook: Qualitative Data Analysis, 2nd edn. Sage, London.

Morawczynski, O. (2009) Exploring the usage \& impact of 'transformational' mobile financial services: The case of M-PESA in Kenya. Journal of Eastern African Studies, 3,509-525.

Palmer, H. \& Conaty, P. (2002) Profiting from Poverty: Why Debt is Big Business in Britain, New Economics Foundation, London.

Panigyrakis, G. G., Theodoridis, P. K. \& Veloutsou, C. A. (2002) All customers are not treated equally: Financial exclusion in isolated Greek isl\&s. Journal of financial Services Marketing,7, 54-66.

Smith, N.C. \& Cooper-Martin, E. (1997) Ethics \& Target Marketing: The Role of Product-Harm \& Consumer Vulnerability. Journal of Marketing, 61,1-20.

Speak, S. (2000) Back to the well: the hidden costs of service exclusion for the network poor. Journal of Consumer Studies \& Home Economics, 24, 49-59.

Ståsett, S. J. (2007) The Ethics of Vulnerability, Social Inclusion \& Social Capital. In Forum for Development Studies. 34, 45-62.

Taylor, S. J. \& Bogdan, R. (1984) Introduction to qualitative research methods: The search for meanings. John Wiley \& Sons, New York.

Viswanathan, M., Sridharan, S. \& Ritchie, R. (2010) Understanding consumption and entrepreneurship in subsistence marketplaces, Journal of Business Research, 63, 570581.

Wallace, A. \& Quilgars, D. (2005) Homelessness \& Financial Exclusion: A Literature Review, Centre for Housing Policy, The University of York, York.

Walsh, G. (2009) Disadvantaged consumers' experiences of marketplace discrimination in customer services. Journal of Marketing Management, 25,143-169.

Wang J, J. \& Tian, Q. (2014) Consumer Vulnerability \& Marketplace Exclusion: A Case of Rural Migrants and Financial Services in China, Journal of Macromarketing, 34, 4556. 
World Bank. (2005) Indicators of Financial Access-Household LevelSurveys, The World Bank, Washington, DC.

World Bank (2008) World Development Indicators, The World Bank, Washington, DC.

Table 1 Participants demographical details

\begin{tabular}{|c|c|c|c|c|c|c|c|}
\hline S\# & Alias & Sex & Age & Occupation & Education & Income & Residence \\
\hline 1 & Jani & $\mathrm{M}$ & 43 & Waterbore worker & High School & $15000-20000$ & Local \\
\hline 2 & Mani & $M$ & 27 & Café Worker & High School & 12,000 & MW \\
\hline 3 & Papu & $\mathrm{M}$ & 26 & Tailor & School Leaver & $17000-18000$ & MW \\
\hline 4 & Khan & M & 44 & Taxi Driver & Illiterate & $15000-16000$ & Local \\
\hline 5 & Bano & FM & 36 & Housemaid & Illiterate & 15000 & MW \\
\hline 6 & Raja & $\mathrm{M}$ & 41 & Vegetable Seller & School Leaver & $15000-17000$ & Local \\
\hline 7 & Izza & FM & 55 & Housewife & School Leaver & 20,000 & Local \\
\hline 8 & Rani & FM & 25 & Housemaid & Illiterate & 8000 & $\mathrm{MW}$ \\
\hline 9 & Pola & M & 29 & Grocery Shopkeeper & Undergraduate & $15000-16000$ & MW \\
\hline 10 & Nomi & $\mathrm{M}$ & 21 & Cashier in Café & Completed School & 11000 & MW \\
\hline 11 & Nori & FM & 40 & Cleaner in School & Illiterate & $7000-8000$ & MW \\
\hline 12 & Babu & $\mathrm{M}$ & 42 & Whitewasher & Completed College & $12000-15000$ & Local \\
\hline 13 & Jelo & FM & 40 & Pvt School Teacher & Completed College & 7000 & Local \\
\hline 14 & Shan & M & 26 & Salesman in a Shop & High School & 10000 & MW \\
\hline 15 & Niaz & $\mathrm{M}$ & 26 & Tailor & Illiterate & $15000-18000$ & MW \\
\hline 16 & Bibi & FM & 45 & Housemaid & Illiterate & 8500 & MW \\
\hline 17 & Babli & FM & 46 & Tailoring from home & Illiterate & $10000-12000$ & MW \\
\hline 18 & Sami & $\mathrm{M}$ & 22 & Grocery Shopkeeper & School Leaver & $15000-20000$ & MW \\
\hline 19 & Bari & $\mathrm{M}$ & 34 & Barber & Illiterate & $10000-12000$ & MW \\
\hline 20 & Rema & FM & 23 & Housemaid & Illiterate & $7000-8000$ & MW \\
\hline 21 & Mana & M & 24 & Cleaner in a firm & School Leaver & 7500 & MW \\
\hline 22 & Malik & $\mathrm{M}$ & 47 & Labour Supervisor & School Leaver & $15000-20000$ & MW \\
\hline 23 & Nelo & FM & 25 & Housemaid & Illiterate & 10000 & MW \\
\hline 24 & Noor & $\mathrm{M}$ & 32 & Tailor & Illiterate & $10000-12000$ & MW \\
\hline 25 & Rifi & FM & 50 & Housemaid & School Leaver & 10000 & MW \\
\hline 26 & Zain & M & 30 & Tailor & School Leaver & $15000-20000$ & MW \\
\hline 27 & Sher & $\mathrm{M}$ & 64 & Dry Cleaner & School Leaver & $10000-15000$ & Local \\
\hline 28 & Kaka & $\mathrm{M}$ & 26 & Welder & School Leaver & 13000 & Local \\
\hline
\end{tabular}

1. Local: Permanently living and working in Rawalpindi or Islamabad.

2. MW: Migrant workers moved alone or with family to City for work from different villages of Pakistan 
Table 2: Internal and external factors influencing vulnerability and exclusion in personal, economic and social spheres

\begin{tabular}{|c|c|c|}
\hline Types of consequences & Internal factors & External factors \\
\hline \multirow[t]{4}{*}{ Personal consequences } & & $\begin{array}{l}\text { Fear of robbery } \\
\text { a. Poor law and order situation } \\
\text { c. Cash salary payment } \\
\text { e. Money transfer through drivers }\end{array}$ \\
\hline & $\begin{array}{l}\text { Time wastage } \\
\text { a. Lack of literacy skills to } \\
\text { understand bank account } \\
\text { opening requirements }\end{array}$ & $\begin{array}{l}\text { Time wastage } \\
\text { a. Banks bill payment procedure } \\
\text { b. Bank staff's poor service } \\
\text { c. Time wastage during an attempt } \\
\text { to open a bank account }\end{array}$ \\
\hline & $\begin{array}{l}\text { Intimidation from lenders } \\
\text { a. Difficulties in paying back } \\
\text { loan due to poverty }\end{array}$ & $\begin{array}{l}\text { Intimidation from lenders } \\
\text { a. Lack of social support } \\
\text { b. Informal lenders aggressive } \\
\text { behaviour }\end{array}$ \\
\hline & $\begin{array}{l}\text { Sense of Deprivation } \\
\text { a. Sense of deprivation due } \\
\text { to poverty }\end{array}$ & $\begin{array}{l}\text { Sense of Deprivation } \\
\text { a. Bank staff discrimination } \\
\text { against the poor }\end{array}$ \\
\hline \multirow[t]{3}{*}{ Economic consequences } & $\begin{array}{l}\text { Difficulties in saving money } \\
\text { a. Lack self-discipline to } \\
\text { save }\end{array}$ & $\begin{array}{l}\text { Difficulties in saving money } \\
\text { a. Difficult to save without a bank } \\
\text { account }\end{array}$ \\
\hline & & $\begin{array}{l}\text { High cost money transfer } \\
\text { a. High charges of SMS-based } \\
\text { money transfer services }\end{array}$ \\
\hline & & $\begin{array}{l}\text { Lack of business opportunities } \\
\text { a. Cannot take high-rate work } \\
\text { from firms because they pay } \\
\text { through cheques or into bank } \\
\text { accounts }\end{array}$ \\
\hline \multirow[t]{2}{*}{ Social consequences } & & $\begin{array}{l}\text { Embarrassment } \\
\text { a. When others learn that an } \\
\text { individual is unbanked. }\end{array}$ \\
\hline & $\begin{array}{l}\text { Damaged relationships } \\
\text { a. Difficulties in paying back } \\
\text { loan due to poverty }\end{array}$ & $\begin{array}{l}\text { Damaged relationships } \\
\text { a. Lack access to short-term } \\
\text { finance. } \\
\text { b. Reliance for loan from } \\
\text { relatives/friends } \\
\text { c. Difficult to decline a loan } \\
\text { request to a close relative }\end{array}$ \\
\hline
\end{tabular}

